\title{
Databases and Simplified Geology for Mineralized Areas, Claims, Mines and Prospects in Colorado
}

\author{
Part A: Data Files and Formats \\ Part B: Figures and Maps \\ Part C: Metadata \\ by Anna B. Wilson
}

Open File Report 03-090

2003

This report is preliminary and has not been reviewed for conformity with U.S. Geological Survey editorial standards. Any use of trade names is for descriptive purposes only and does not imply endorsement by the U.S. Government. Although these data have been used by the USGS and have been successfully imported into a number of database and spreadsheet programs, no warranty, expressed or implied, is made by the USGS as to how successfully or accurately the data can be imported into any specific application software running on any specific hardware platform. The fact of distribution shall not constitute any such warranty, and no responsibility is assumed by the USGS in connection therewith.

\section{U.S. DEPARTMENT OF THE INTERIOR}

U.S. GEOLOGICAL SURVEY

${ }^{1}$ U.S. Geological Survey, Denver, Colorado 


\section{CONTENTS}

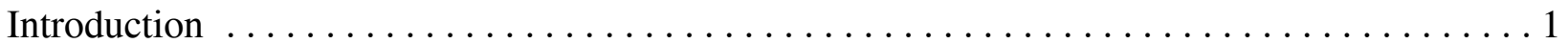

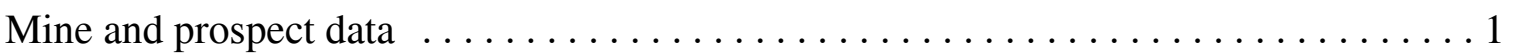

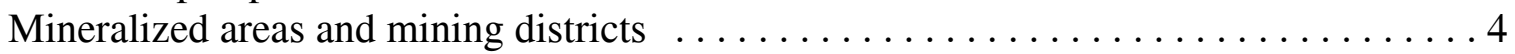

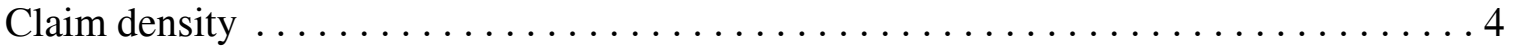

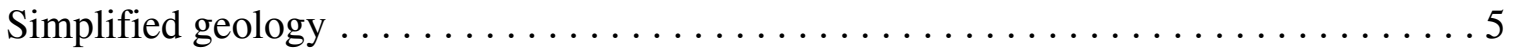

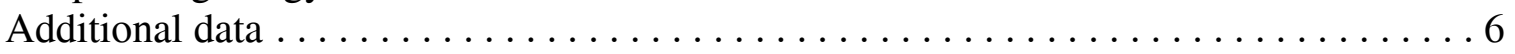

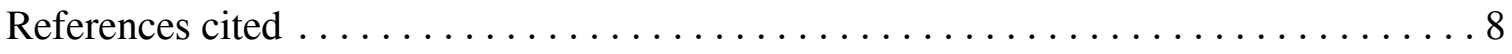

APPENDICES

A. Data files showing file names, formats, and projections $\ldots \ldots \ldots \ldots \ldots \ldots \ldots$

B. Files used to construct Workspaces (.wor) or Projects (.apr or .aep) $\ldots \ldots \ldots \ldots \ldots$

C. List of files included in Figures 1-8 (PartB\PDF ...) $\ldots \ldots \ldots \ldots \ldots \ldots \ldots \ldots \ldots$ 


\section{FILES ON CD-ROM}

Root Directory:

Introduction (text) . CO_text.pdf

Information sources listed in MRDS mine and prospect database

Published or verifiable sources $\ldots \ldots \ldots \ldots \ldots \ldots \ldots$ CO_mrds_published_refs.pdf

Unpublished or unverifiable sources $\ldots \ldots \ldots \ldots \ldots$. CO_mrds_unpublished_refs.pdf

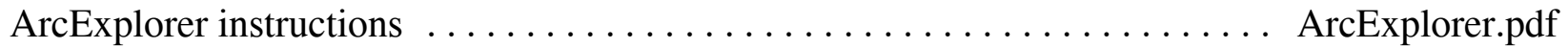

ArcExplorer v.2 (Program installation file) $\ldots \ldots \ldots \ldots \ldots \ldots \ldots \ldots \ldots \ldots$ ae2setup.exe

Geology ArcExplorer project file $\ldots \ldots \ldots \ldots \ldots \ldots \ldots \ldots \ldots \ldots \ldots \ldots$ CO_geol.aep

Mines and prospects ArcExplorer project file $\ldots \ldots \ldots \ldots \ldots \ldots \ldots \ldots \ldots$ CO_data.aep

Part A:

Data Files and Formats

MRDS Mine and Prospect Database (original, unedited) ...... CO_MRDS.xls

MAS/MILS database (original, unedited) ........................

MapInfo (.tab. dat, .id, .map, and ind. [if applicable] files including CO_data.wor and CO_geol.wor workspaces) AND ArcView (.shp, .shx, .dbf files including CO_data.apr and $\mathrm{CO} \_$geol.apr projects)

MRDS mines and prospects $\ldots \ldots \ldots \ldots \ldots \ldots \ldots \ldots \ldots$ CO_MRDS

MAS/MILS mines and prospects $\ldots \ldots \ldots \ldots \ldots \ldots \ldots \ldots \ldots$ CO_MAS

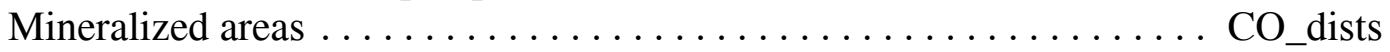

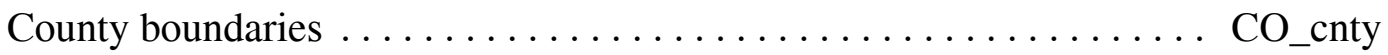

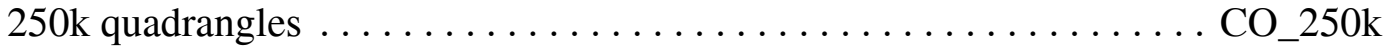

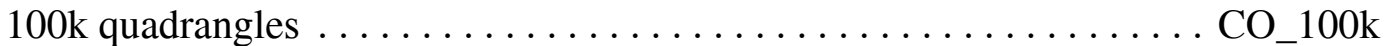

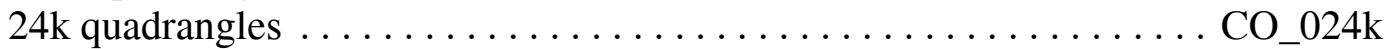

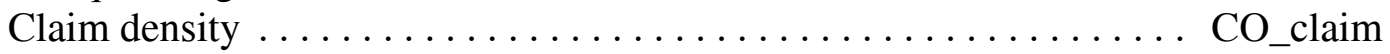

Public Lands Survey System $\ldots \ldots \ldots \ldots \ldots \ldots \ldots \ldots \ldots \ldots$ CO_PLSS

Land ownership $\ldots \ldots \ldots \ldots \ldots \ldots \ldots \ldots \ldots \ldots \ldots \ldots \ldots \ldots \ldots \ldots \ldots$ CO_publd

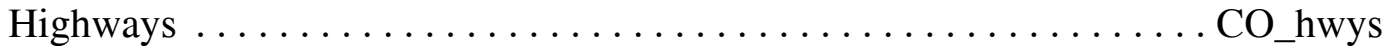

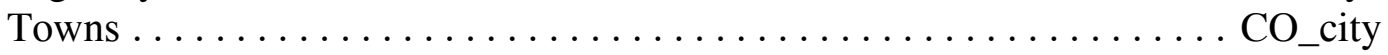

Colorado state $\ldots \ldots \ldots \ldots \ldots \ldots \ldots \ldots \ldots \ldots \ldots \ldots \ldots \ldots \ldots \ldots \ldots \ldots \ldots$ CO_state

Industrial mineral mines $\ldots \ldots \ldots \ldots \ldots \ldots \ldots \ldots \ldots \ldots \ldots \ldots$ CO_indus

Industrial mineral mine permit locations $\ldots \ldots \ldots \ldots \ldots \ldots \ldots$ CO_permits

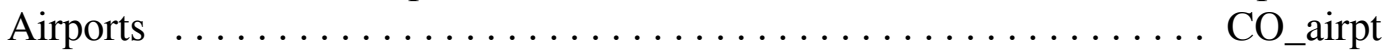

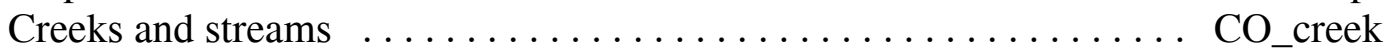

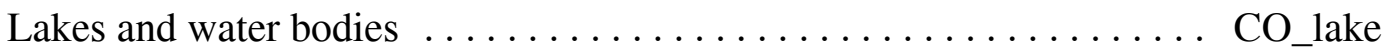

Colorado mineral belt $\ldots \ldots \ldots \ldots \ldots \ldots \ldots \ldots \ldots \ldots \ldots \ldots$ CO_mb

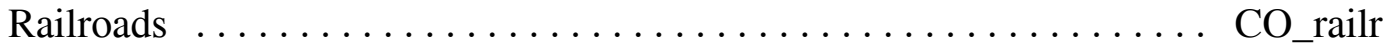

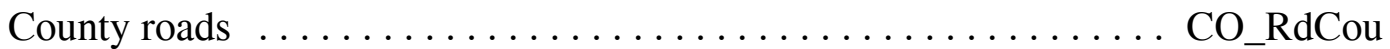

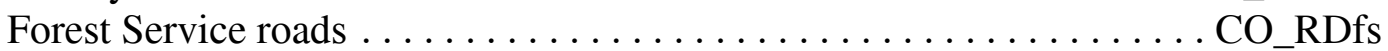

Local roads .............................. CO_RdLoc

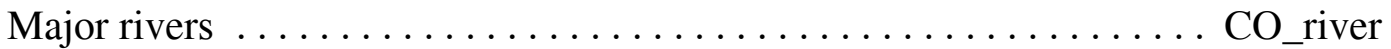

Major water bodies (lakes, reservoirs, wide rivers) $\ldots \ldots \ldots \ldots \ldots$ CO_water 
Water bodies (as mapped on Tweto, 1979; Green, 1992)) . . . . . . H2O

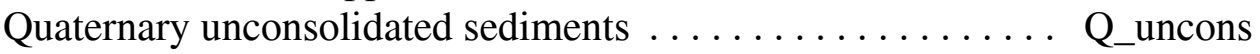

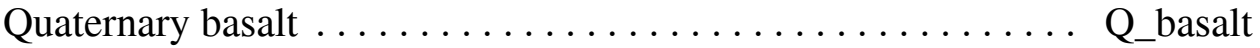

Tertiary unconsolidated sediments $\ldots \ldots \ldots \ldots \ldots \ldots \ldots$ T_uncons

Tertiary sedimentary rocks $\ldots \ldots \ldots \ldots \ldots \ldots \ldots \ldots \ldots \ldots \ldots \ldots$. $\ldots \ldots \ldots$

Tertiary volcaniclastic rocks $\ldots \ldots \ldots \ldots \ldots \ldots \ldots \ldots T_{-}$vclast

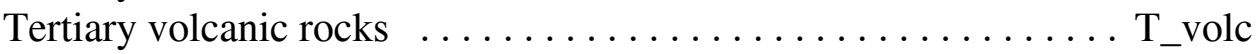

Tertiary plutonic rocks $\ldots \ldots \ldots \ldots \ldots \ldots \ldots \ldots \ldots \ldots \ldots$ T_pluton

Cretaceous sedimentary rocks $\ldots \ldots \ldots \ldots \ldots \ldots \ldots \ldots \ldots \ldots \ldots \ldots$ K_sed

Cretaceous and Jurassic sedimentary rocks . . . . . . . . . . KJ_sed

Jurassic sedimentary $\operatorname{rocks} \ldots \ldots \ldots \ldots \ldots \ldots \ldots \ldots \ldots \ldots \ldots$ J_sed

Jurassic and Triassic sedimentary rocks $\ldots \ldots \ldots \ldots \ldots \ldots \ldots$ JTr_sed

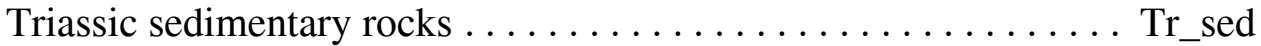

Triassic and Permian sedimentary rocks $\ldots \ldots \ldots \ldots \ldots \ldots$ TrP_sed

Permian sedimentary rocks $\ldots \ldots \ldots \ldots \ldots \ldots \ldots \ldots$ Perm_sed

Triassic, Permian, and Pennsylvanian sedimentary rocks ... Tr_Penn_sed

Permian and Pennsylvanian sedimentary rocks . . . . . . . P_Penn_sed

Pennsylvanian sedimentary rocks $\ldots \ldots \ldots \ldots \ldots \ldots \ldots$ Penn_sed

Mississippian to Cambrian sedimentary rocks . . . . . . . MDOC_sed

Mesozoic sedimentary rocks $\ldots \ldots \ldots \ldots \ldots \ldots \ldots \ldots \ldots \ldots \ldots \ldots \ldots \ldots$ Mzsed

Cambrian sedimentary rocks $\ldots \ldots \ldots \ldots \ldots \ldots$ Camb_sed

Cambrian intrusive rocks $\ldots \ldots \ldots \ldots \ldots \ldots \ldots \ldots \ldots \ldots \ldots \ldots \ldots \ldots \ldots$ Cambint

Middle Proterozoic sedimentary rocks $\ldots \ldots \ldots \ldots \ldots \ldots$ Y_sed

Middle and Early Proterozoic metamorphic rocks . . . . . . . YX_met

Middle and Early Proterozoic intrusive rocks $\ldots \ldots \ldots \ldots \ldots$ YX_intr

Archean metamorphic rocks $\ldots \ldots \ldots \ldots \ldots \ldots \ldots \ldots \ldots \ldots$. met

Volcanic necks ................ CO_asterisk_volcanicneck

Geologic map units, attributed . . . . . . . . . CO_attributed_geology

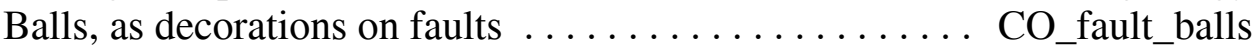

Bars, as decorations on faults $\ldots \ldots \ldots \ldots \ldots \ldots$ CO_fault_bars

Faults, all types, as lines ............. CO_faults_all_types

Faults and contacts, as lines (contains all of CO_faults_all_types)

$\ldots \ldots \ldots \ldots \ldots \ldots \ldots$ CO_faults_and_contacts

Structural axes (anticlines, synclines, etc.) ....... CO_structure_axes

Thin rock units such as dikes and sills .... CO_thin_units_dikes_as_lines

Triangles, as decorations on thrust faults ...... CO_thrustfault_triangles

*File names in the ArcView directory include_region,_polyline, or_point, indicating the type of data contained, after the name given above. 
Part B. Illustrations (.pdf)

Adobe Acrobat Reader (installation file) ............. AcroReader51_ENU_full.exe PDF (Figures 1-8, all in .pdf format)

Figure 1. Colorado index map $\ldots \ldots \ldots \ldots \ldots \ldots \ldots \ldots \ldots$ CO_index

Figure 2. Mineralized areas $\ldots \ldots \ldots \ldots \ldots \ldots \ldots \ldots \ldots \ldots \ldots \ldots \ldots \ldots$ CO_mnarea

Figure 3. Distribution of metallic minerals ................ CO_metdep

Figure 4. Land ownership ......................... CO_lndown

Figure 5. Simplified geologic map $\ldots \ldots \ldots \ldots \ldots \ldots \ldots \ldots \ldots$ CO_geol

Figure 6. Claim activity map $\ldots \ldots \ldots \ldots \ldots \ldots \ldots \ldots \ldots \ldots \ldots \ldots$ CO_minclm

Figure 7. Distribution of mineral deposits $\ldots \ldots \ldots \ldots \ldots \ldots \ldots$ CO_allmin

Figure 8. Placer claims and deposits ................... CO_placer

Part C: Metadata (all are ASCII text files, .txt)

Geology $\ldots \ldots \ldots \ldots \ldots \ldots \ldots \ldots \ldots \ldots \ldots \ldots$ ofr_92_0507_metadata

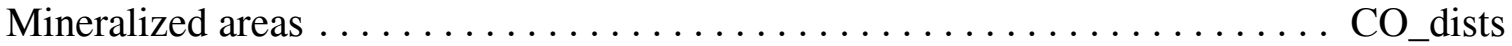

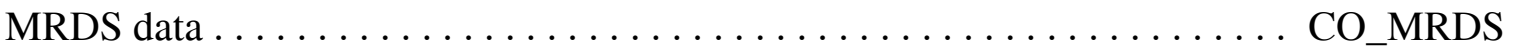

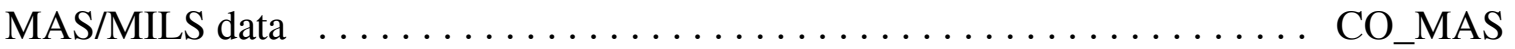

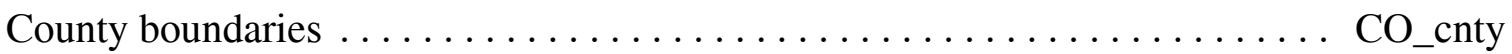

250,000-, 1:100,00-, and 1:24,000-scale Quadrangles $\ldots \ldots \ldots \ldots \ldots \ldots$ CO_quads

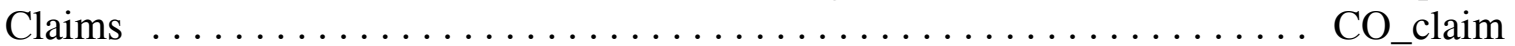

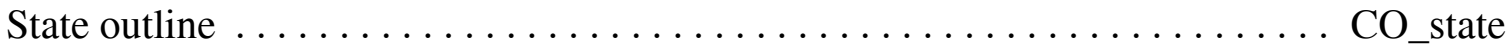

Public Lands Survey System $\ldots \ldots \ldots \ldots \ldots \ldots \ldots \ldots \ldots \ldots \ldots \ldots \ldots \ldots \ldots \ldots \ldots \ldots$

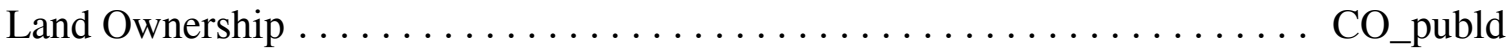

Colorado mineral belt $\ldots \ldots \ldots \ldots \ldots \ldots \ldots \ldots \ldots \ldots \ldots \ldots \ldots \ldots \ldots \ldots \ldots \ldots \ldots$

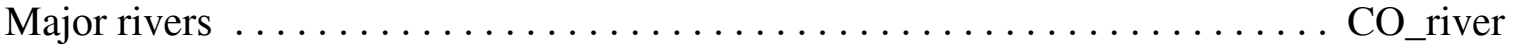

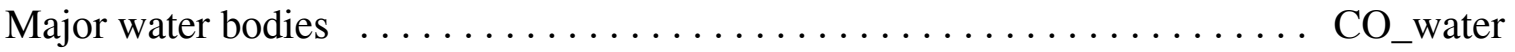

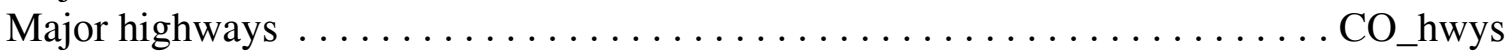

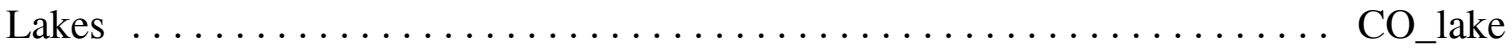

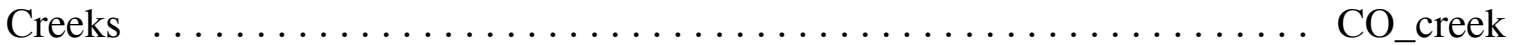

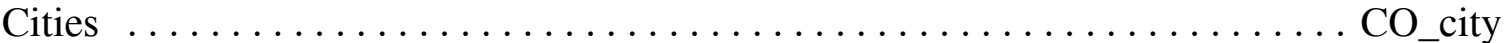

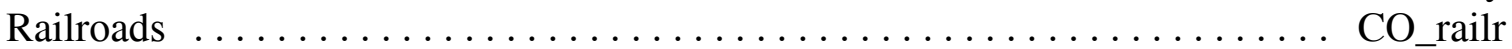

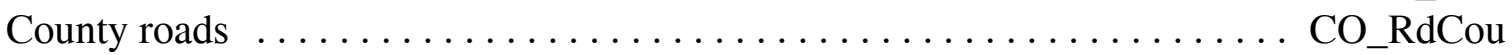

Forest Service roads $\ldots \ldots \ldots \ldots \ldots \ldots \ldots \ldots \ldots \ldots \ldots \ldots \ldots \ldots$, CO_RdFS

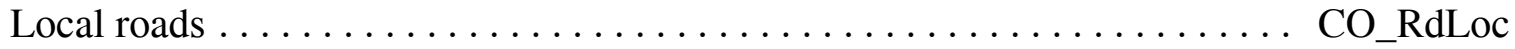

Colorado Department of Transportation (CDOT directory) airports

railroads

Forest Service roads

streams

Highways

lakes

Counties

County roads

Land status data

Local roads

Major roads

Municipal boundaries 
Files on CD

DATA FILES

CO_MRDS

CO_MAS

CO_250k

CO_100k

CO_024k

CO_state

CO_cnty

CO_dists

CO_city

CO_hwys

CO_claim

CO_PLSS

CO_publd

CO_airpt

CO_creek

CO_lake

CO_river

CO_water

CO_railr

CO_RdCou

CO_Rdfs

CO_RdLoc

CO_indus

CO_perm

CO_mb $\underline{\text { SIMPLIFIED GEOLOGY }}$

CO_geol

$\mathrm{H} 2 \mathrm{O}$

Q_uncons

Q_basalt

T_uncons

T_sed

T_vclast

T_volc

T_pluton

K_sed

KJ_sed

J_sed

JTr_sed

Tr_sed

TrP_sed

Perm_sed

Tr_Penn_sed

P_Perm_sed

Penn_sed

Mz_sed

MDOC_sed

Camb_sed

Camb_intr

Y_sed

YX_intr

YX_met

W_met

pCplut

\section{GEOLOGIC MAP**}

CO_attributed_geology

CO_thin_units_dikes_as_lines

CO_faults_and_contacts

CO_faults_all_types

CO_asterisk_volcanicneck

CO_structure_axes

CO_fault_bars

CO_fault_balls

CO_thrustfault_triangles
*(Geologic map layers from Green's 1992 geologic map formatted for MapInfo and ArcView, and attributed by Wilson in 2002.

CO_thin_units_dikes_as_lines created by selecting the original "line_line.e00" file of Green.

CO_faults_and_contacts from the "contact_line.e00" file. All other datasets created by selecting individual codes from Green's data files.) 


\section{INTRODUCTION}

This data release contains mineral resource data for metallic and nonmetallic mineral sites in the State of Colorado. Along with the resource data, there is additional data, such as mineralized areas and mining districts; mine, prospect and commodity information; claim density by section; county boundaries; quadrangles; and simplified geology. All the geographic data are provided in formats for two commonly used Geographic Information Systems (GIS) software packages (MapInfo and ESRI's ArcView). Not only does GIS software allow the data to be shown as layers in "map" views that can be displayed with various geographic and geologic data, but the data can be queried and analyzed relative to data in any of the layers. Free shareware, ArcExplorer, is provided with this report so users may display the data in "map" views and query the various datasets (Appendix A) without requiring a GIS program such as Arc/Info ${ }^{1}$, ArcView ${ }^{1}$, or MapInfo ${ }^{1}$. Additional data, such as original and unedited mine and prospect files, bibliography and references, and text are provided in appropriate formats such as in spreadsheets (Microsoft Excel), or documents (text, WordPerfect, or Microsoft Word).

Explanatory material is in the Introduction (and root directory on the CD release and online). Part A includes all the data files with subdirectories for ArcView and MapInfo. Part B contains illustrations as .pdf maps (an installation file for Adobe Acrobat Reader for viewing the .pdf files is on the $\mathrm{CD}$ ). Part $\mathrm{C}$ contains metadata, explanatory details on the structure and content of each data file.

To use ArcExplorer, run ae2setup. Once the program is installed you may work with either of the ArcExplorer project files (CO_geol.aep or CO_data.aep) or create your own. Run ArcExplorer and then open the .aep file from within the program.

\section{MINE AND PROSPECT DATA}

Mineral resource data for metallic and nonmetallic mineral sites in the State of Colorado were initially extracted from the U.S. Geological Survey's large worldwide databases: Mineral Resources Data System (MRDS) and Minerals Availabilty System/Mineral Industry Location

\footnotetext{
${ }^{1}$ Registered trademark of ESRI

${ }^{2}$ Registered trademark of MapInfo Corporation
} 
System (MAS/MILS) (McFaul and others, 2000; U.S. Geological Survey, 2001). For this report, many of the existing records for Colorado in both databases were corrected or revised. The changes have not yet been incorporated into the USGS's active databases. This report uses the modified and revised records.

The MRDS and MAS/MILS (McFaul and others, 2000; U.S. Geological Survey, 2001) databases were originally compiled for different purposes and contain different information, although some information is common to both. MRDS was constructed by the USGS and MAS/MILS was built by the U.S. Bureau of Mines (USBM). After the Bureau of Mines was abolished in 1996, custody of MAS/MILS was transferred to the USGS. MAS/MILS includes records for geothermal, coal, ash, nitrogen, oil, and sand and gravel, none of which are normally included in the MRDS database. The MRDS database is primarily descriptive and contains historical data about mineral deposit sites, including mines, prospects, and occurrences, deposit description, geologic characteristics, production, reserves, potential resources, and references. Most of the additions and corrections to the MRDS database in this report are limited to location information, commodities, geologic data, and deposit types. MAS/MILS contains less geologic information but more information regarding extraction and processing operations.

In each database, records are identified by a unique alphanumeric code and describe a site. A "site" may be a single mine, block of claims, group of mines or workings, mining district, or even a region. Each record contains the location (usually by latitude and longitude), name of the deposit, information about the mineral deposit, and commodities present. Locations for many, but by no means all, of the metallic mineral deposits in the MRDS database were verified by plotting locations given in the original references on 1:24,000 scale USGS digital raster graphics images (DRGs) of topographic maps, and digitizing them on screen. All the data from both databases were imported into GIS (MapInfo) and the locations of dozens of mislocated deposits were adjusted so that they would plot in Colorado. In addition, the locations of a large number of deposits were adjusted to plot within the correct county, quadrangle, or township and range. Each of these adjustments was made for different reasons, with different levels of confidence, none of which are recorded in the database. There will certainly be erroneous locations-but in nearly every case, they will be better located than previously. 
Minor attempts were made to coordinate or reconcile the difference between the locations in the MRDS and MAS/MILS databases. In general, the MRDS location records the approximate center of the deposit, whereas the MAS/MILS location is often the main access to the deposit. In some cases the two locations can be many miles apart. In the CO_MRDS database, the second data column contains the corresponding MAS/MILS record number, if it could be determined. Many fewer MAS/MILS sites contain a corresponding MRDS record (column labeled "GEOLSURV"). For many records, where MRDS and MAS/MILS records clearly correlate, the locations were adjusted to plot at the same point. It must be emphasized that these locations are estimates based on descriptions provided in the literature, various databases, topographic, or geologic maps-they have not been measured by a geographic positioning system (GPS) in the field.

\section{MRDS data structure}

The original MRDS database contains at least 226 variable-length fields. Many records exceed the approximately 254 characters per field and 4000 character limitation per record of most GIS programs. Due to this constraint, we have restructured the data to be compatible with MapInfo and ESRI's ArcView. Certain fields from the original database were extracted, based on the percentage of data population for each field and its importance related to mineral resource assessment. Some of these 5,470 records have been newly created, most others were revised in some way in the course of preparing data for this publication. The selected fields and their formats in CO_MRDS are listed in the corresponding metadata file in the Part C, the metadata subdirectory.

\section{MAS/MILS data structure}

16,151 deposits are included in the MAS/MILS database. This database contains many deposit types and mining-related sites that are not included in the MRDS database such as mills, tunnel sites, and non-metallic resources such as coal, sand and gravel, and geothermal energy. Several fields with minimal information or deemed non-essential for this study were deleted. 
The field "quad024k" contains the name of the 24,000 scale topographic map on which the deposit is located. The 71 fields and their formats in CO_MAS are listed in the metadata.

\section{MINERALIZED AREAS AND MINING DISTRICTS}

Mining district boundaries were modified from an unpublished ArcInfo cover developed by the USBM from data presented on the Metallic and Industrial Mineral Map of Colorado (Harris and others, 1985). Based on deposit types, commodities present, and mineral locations in CO_MRDS and CO_MAS, overlain on geology, the map has been adapted to show mineralized areas. A mineralized area encloses a geographic area that is defined by the presence of mines, prospects, and/or mineralized occurrences that belong to one deposit-type or a group of genetically related deposit-types in a distinct geologic setting. A mineralized area may include an entire district or portions of several mining districts. Mineralized areas differ from mining districts because they are based on geology, and on similarity of deposits and related commodities. Districts are defined in geographical terms and may contain completely unrelated deposit types.

Thirty mineralized areas include metallic deposits exclusive of sedimentary uranium deposits. Sixteen areas primarily contain sedimentary uranium deposits and an additional three areas primarily contain bentonite. Not all mineralized areas contain mines that are included in the MRDS or MAS/MILS databases.

\section{CLAIM DENSITY}

Claim density data for Colorado (Hyndman and Campbell, 1999) are combined with the Colorado Public Land Survey grid (CO_PLSS) as a single file, CO_claims. Total counts of open and closed claims in each section between 1976 and 1996 are given in whole numbers for Lode, Placer, Mill site, and Tunnel site. Sections with no recorded claims in the same time period are not included. Complete description of these data can be found in Hyndman and Campbell's 1999 USGS Open-File Report 99-542. These claims often border the historic districts where 
many of the known deposits are on patented ground. Unfortunately, the claim information does not date back to the 1800 s. If they did, the distribution may look quite different.

\section{SIMPLIFIED GEOLOGY}

Simplified geology was constructed from Green's (1992) digital rendering of Tweto's (1979) geologic map of Colorado. For this report, the ArcInfo coverages were imported and converted to MapInfo where map units were combined to create a simplified map with only 25 combined rock units and another unit for water bodies. The 25 combined units include:

$\begin{array}{ll}\text { Q_uncons } & \text { Quaternary unconsolidated sediments } \\ \text { Q_basalt } & \text { Quaternary igneous rocks } \\ \text { T_uncons } & \text { Tertiary unconsolidated rocks } \\ \text { T_sed } & \text { Tertiary sedimentary rocks } \\ \text { T_vclast } & \text { Tertiary volcaniclastic rocks } \\ \text { T_volc } & \text { Tertiary volcanic rocks } \\ \text { T_plut } & \text { Tertiary plutonic rocks } \\ \text { K_sed } & \text { Cretaceous sedimentary rocks } \\ \text { KJ_sed } & \text { Cretaceous and Jurassic sedimentary rocks } \\ \text { J_sed } & \text { Jurassic sedimentary rocks } \\ \text { JTr_sed } & \text { Jurassic and Triassic sedimentary rocks } \\ \text { TrP_sed } & \text { Triassic and Permian sedimentary rocks } \\ \text { Perm_sed } & \text { Permian sedimentary rocks } \\ \text { Tr_Penn_sed } & \text { Triassic, Permian, and Pennsylvanian sedimentary rocks } \\ \text { P_Perm_sed } & \text { Pennsylvanian and Permian sedimentary rocks } \\ \text { Penn_sed } & \text { Pennsylvanian sedimentary rocks } \\ \text { Mz_sed } & \text { Mesozoic sedimentary rocks, undifferentiated } \\ \text { MDOC_sed } & \text { Mississippian to Cambrian sedimentary rocks } \\ \text { Camb_sed } & \text { Cambrian sedimentary rocks } \\ \text { Camb_intr } & \text { Cambrian intrusive rocks } \\ \text { Y_sed } & \text { Middle Proterozoic sedimentary rocks } \\ \text { YX_intr } & \text { Early and Middle Proterozoic sedimentary rocks } \\ \text { YX_met } & \text { Early and Middle Proterozoic metamorphic rocks } \\ \text { W_met } & \text { Archean metamorphic rocks } \\ \text { H20 } & \text { Major water bodies, lakes, reservoirs, rivers } \\ & \end{array}$

For more geologic detail, an “attributed" version of Green's digital map is included (CO_attributed_geology). Attributing is subject to interpretation. However, it allows the user to query the map based on dominant lithology (the rock type most prevalent in the unit, general lithology (an overall estimate of the rock type), or age, as interpreted by the attributer. Also included are files containing the very thin units (CO_thin_units_dikes_as_lines) and volcanic 
necks (CO_asterisk_volcanicnecks) that are not represented as polygons, geologic faults and contacts (CO_faults_and_contacts), structural axes (CO_structure_axes), and faults

(CO_faults_all_types). The geologic symbols that decorate the faults, such as bar and balls, and triangles on the overriding plate of thrust faults are in separate files (CO_fault_balls, CO_fault_bars, CO_thrustfault_triangles). For details on specific line codes see the metadata by Green (1992).

Viewing mineral deposits by commodity or mineral deposit type relative to the host geology is valuable for determining the characteristics and distribution of the deposits. For additional detail, the user should retrieve the original maps (Green, 1992; or Tweto, 1979). Be aware, that due to the uncertainties in the location of the deposits in MRDS and MAS/MILS and the scale of the geologic map (1:500,000), mines may not plot within the host rock listed in the databases for the deposits.

\section{ADDITIONAL DATA}

Other datasets are included for general interest and ease of use. These include a general outline of Colorado, the county boundaries, maps identifying the 1:24,000, 1:100,000, and 1:250,000 topographic maps, public land ownership (showing such distinctions as state lands, National Forests, BLM lands, reservations, etc.), major and minor roads, towns, rivers and major water bodies, streams, location of industrial mineral deposits and permitted mines (Keller and others, 2002), and railroads. A complete list is found in the Table of Contents, Appendix A, or in the CD directory. Each of the topo grids was created especially for this report based on other published datasets, none of which were imported correctly or accurately enough for this report. Most other datasets were modified from data available publicly on the internet from BLM, Colorado Department of Transportation, and other sources. Metadata for each dataset clearly explains its origin and how it was modified for this report.

Many MRDS records contain a list of references used by the original compilers to create the original data record. This field, may in fact, be the single most important field in the database. However, the citations were not in any standard format. For this data release, all the references have been standardized in a shortened format in the "refs" field: first author ("and 
others", if appropriate), date, condensed and abbreviated mode of publication, page number (if given). All of the published and verifiable references were extracted from the database and the complete citation listed alphabetically by author is in CO_MRDS_published_refs.pdf.

References that are unpublished, could not be verified, located, deciphered, or were clearly wrong, are in CO_MRDS_unpublished_refs.pdf. The bibliography very well might be the most useful feature of this report. 


\section{REFERENCES CITED}

Green, G.N., 1992, The digital geologic map of Colorado in ARC/INFO format: U.S. Geological Survey Open-File Report 92-507.

Harris, R.E., Hausel, W.D., Meyer, J.E., compilers, 1985, Metallic and industrial minerals map of Colorado: Geological Survey of Colorado, Map Series 14, scale 1:500,000.

Hyndman, P.C., and Campbell, H.W., 1999, Digital mining claim density map for Federal lands in Colorado--1996: U.S. Geological Survey Open-File Report 99-542.

Keller, J.W., Phillips, R.C., and Morgan, K., 2002, Digital inventory of industrial mineral mines and mine permit locations in Colorado (includes shapefiles and ESRI Arc Explorer software): Colorado Geological Survey Information Series 62.

McFaul, E.J., Mason, G.T., Jr., Ferguson, W.B., and Lipin, B.R., 2000, U.S. Geological Survey mineral databases--MRDS and MAS/MILS: U.S. Geological Survey Digital Data Series DDS-52.

Tweto, Ogden, 1979, Geologic map of Colorado: U.S. Geological Survey Special Geologic Map, scale 1:500,000.

U.S. Bureau of Mines, 1996, Minerals Availability System (MAS) database-Deposit information manual and data dictionary, U.S. Bureau of Mines.

U.S. Geological Survey, 2001, Mineral Resource Data System [MRDS: active computer file; data available from U.S. Geological Survey, Mineral Resources Program, Mail Stop 913, National Center, Reston, VA 21092].

U.S. Geological Survey, 2001, Minerals Availability System [MAS: active computer file; data available from U.S. Geological Survey, Minerals Information Team (formerly U.S. Bureau of Mines), Building 20, Denver Federal Center, Denver CO 80225]. 


\section{Appendix A. Data files showing file names, formats, and projections.}

[Three character file extensions throughout this report are as follows: .shp, ArcView shape file; .tab, MapInfo table file; .xls, Microsoft Excel spreadsheet; .met, metadata in text format; .aep, ArcExplorer Project file; pdf, Adobe Acrobat Reader portable document file; *, refers to any extension. All spatial data is recorded in latitude and longitude coordinates and is unprojected.]

\begin{tabular}{|c|c|c|c|c|c|c|}
\hline DATA TYPE & FILE &. $\operatorname{shp}$ &.$t a b$ &.$x l s$ & .met & $\begin{array}{l}\text { projecti } \\
\text { on }\end{array}$ \\
\hline MRDS & CO_MRDS & $\mathrm{X}$ & $\mathrm{X}$ & $\mathrm{X}$ & $\mathrm{X}$ & latlong \\
\hline MAS/MILS & CO_MAS & $\mathrm{X}$ & $\mathrm{X}$ & $\mathrm{X}$ & $\mathrm{X}$ & latlong \\
\hline $250 \mathrm{k}$ quadrangles & CO_250k & $\mathrm{X}$ & $\mathrm{X}$ & & $\mathrm{X}$ & latlong \\
\hline 100k quadrangles & CO_100k & $\mathrm{X}$ & $\mathrm{X}$ & & $\mathrm{X}$ & latlong \\
\hline 24k quadrangles & CO_024k & $\mathrm{X}$ & $\mathrm{X}$ & & $\mathrm{X}$ & latlong \\
\hline claim density & CO_claim & $\mathrm{X}$ & $\mathrm{X}$ & & $\mathrm{X}$ & latlong \\
\hline county boundaries & CO_cnty & $\mathrm{X}$ & $\mathrm{X}$ & & $\mathrm{X}$ & latlong \\
\hline public land survey system & CO_PLSS & $\mathrm{X}$ & $\mathrm{X}$ & & $\mathrm{X}$ & latlong \\
\hline public land ownership & CO_publd & $\mathrm{X}$ & $\mathrm{X}$ & & $\mathrm{X}$ & latlong \\
\hline mineralized areas/districts & CO_dists & $\mathrm{X}$ & $\mathrm{X}$ & & $\mathrm{X}$ & latlong \\
\hline towns/cities & CO_city & $\mathrm{X}$ & $\mathrm{X}$ & & $\mathrm{X}$ & latlong \\
\hline highways & CO_hwys & $\mathrm{X}$ & $\mathrm{X}$ & & $\mathrm{X}$ & latlong \\
\hline local roads & CO_RdLoc & $\mathrm{X}$ & $\mathrm{X}$ & & $\mathrm{X}$ & latlong \\
\hline county roads & CO_RdCou & $\mathrm{X}$ & $\mathrm{X}$ & & $\mathrm{X}$ & latlong \\
\hline forest roads & CO_Rdfs & $\mathrm{X}$ & $\mathrm{X}$ & & $\mathrm{X}$ & latlong \\
\hline railroad lines & CO_railr & $\mathrm{X}$ & $\mathrm{X}$ & & $\mathrm{X}$ & latlong \\
\hline airports & CO_airpt & $\mathrm{X}$ & $\mathrm{X}$ & & $\mathrm{X}$ & latlong \\
\hline rivers & CO_river & $\mathrm{X}$ & $\mathrm{X}$ & & $\mathrm{X}$ & latlong \\
\hline major water bodies & CO_water & $\mathrm{X}$ & $\mathrm{X}$ & & $\mathrm{X}$ & latlong \\
\hline creeks and streams & CO_creek & $\mathrm{X}$ & $\mathrm{X}$ & & $\mathrm{X}$ & latlong \\
\hline lakes & CO_lake & $\mathrm{X}$ & $\mathrm{X}$ & & $\mathrm{X}$ & latlong \\
\hline state outline & CO_state & $\mathrm{X}$ & $\mathrm{X}$ & & $\mathrm{X}$ & latlong \\
\hline industrial mineral mines & CO_indus & $\mathrm{X}$ & $\mathrm{X}$ & & $\mathrm{X}$ & latlong \\
\hline industrial permits & CO_perm & $\mathrm{X}$ & $\mathrm{X}$ & & $\mathrm{X}$ & latlong \\
\hline Colorado mineral belt & CO_mb & $\mathrm{X}$ & $\mathrm{X}$ & & $\mathrm{X}$ & latlong \\
\hline \multirow{2}{*}{ Geology } & CO geol & $\mathrm{X}$ & $\mathrm{X}$ & & $\mathrm{X}$ & latlong \\
\hline & $\begin{array}{l}\text { H2O, Q_uncons, Q_basalt, } \\
\text { T_uncons, T_sed, T_vclast, T_volc, } \\
\text { T_pluton, K_sed, KJ_sed, J_sed, } \\
\text { JTr_sed, Tr_sed, TrP_sed, Perm_sed, } \\
\text { Tr_Penn_sed, P_Perm_sed, } \\
\text { Penn_sed, Mz_sed, MDOC_sed, } \\
\text { Camb_sed, Camb_int, Y_sed, } \\
\text { YX_intr, YX_met, W_met }\end{array}$ & $\mathrm{X}$ & $\mathrm{X}$ & & & latlong \\
\hline Detailed Geology & $\begin{array}{l}\text { CO_asterisk_volcanicneck, } \\
\text { CO_attributed_geology, } \\
\text { CO_fault_balls, CO_fault_bars, } \\
\text { CO_faults_all_types, } \\
\text { CO_faults_and_contacts, } \\
\text { CO_structure_axes, } \\
\text { CO_thin_units_dikes_as_lines, } \\
\text { CO_thrustfault_triangles }\end{array}$ & $\mathrm{X}$ & $\mathrm{X}$ & & & latlong \\
\hline
\end{tabular}


Appendix B. ArcView shape (.shp) files used to construct ArcExplorer project (aep) and ArcView Project (.apr) files and MapInfo (.tab) files used to construct MapInfo workspace (.wor) files.

\begin{tabular}{|c|c|}
\hline PROJECT/WORKSPACE & FILE \\
\hline (.AEP, .APR, .WOR) & (.shp, .tab) \\
\hline \multirow[t]{13}{*}{ CO_DATA } & CO_MRDS \\
\hline & CO_MAS \\
\hline & CO_250k \\
\hline & CO_100k \\
\hline & CO_024k \\
\hline & CO_cnty \\
\hline & CO_state \\
\hline & CO_claim \\
\hline & CO_publd \\
\hline & CO_PLSS \\
\hline & CO_hwys \\
\hline & CO_town \\
\hline & CO_dists \\
\hline \multirow[t]{26}{*}{ CO_GEOL } & $\mathrm{H} 2 \mathrm{O}$ \\
\hline & Q_uncons \\
\hline & Q_basalt \\
\hline & T_uncons \\
\hline & T_sed \\
\hline & T_vclast \\
\hline & $T_{\text {_volc }}$ \\
\hline & T_pluton \\
\hline & K_sed \\
\hline & KJ_sed \\
\hline & J_sed \\
\hline & JTr_sed \\
\hline & Tr_sed \\
\hline & TrP_sed \\
\hline & Perm_sed \\
\hline & Tr_Penn_sed \\
\hline & P_Perm_sed \\
\hline & Penn_sed \\
\hline & Mz_sed \\
\hline & MDOC_sed \\
\hline & Camb_sed \\
\hline & Camb_int \\
\hline & Y_sed \\
\hline & YX_intr \\
\hline & YX_met \\
\hline & W_met \\
\hline
\end{tabular}




\begin{tabular}{|c|c|c|}
\hline FIGURE & CONTENT (.pdf filename) & FILES USED \\
\hline \multirow[t]{4}{*}{1} & Index map & CO_state \\
\hline & (CO_index.pdf) & CO_city \\
\hline & & CO_cnty \\
\hline & & CO_hwys \\
\hline \multirow[t]{3}{*}{2} & Mineralized areas & CO_state \\
\hline & (CO_mnarea.pdf) & CO_dists \\
\hline & & CO_cnty \\
\hline \multirow{3}{*}{3} & Metallic mineral deposits & CO MRDS (thematic) \\
\hline & (CO_metdep.pdf) & CO_MAS (thematic) \\
\hline & & CO_cnty \\
\hline \multirow[t]{2}{*}{4} & Land Ownership & CO_publd (thematic) \\
\hline & (CO_lndown.pdf) & \\
\hline 5 & $\begin{array}{l}\text { Simplified geologic map } \\
\text { (CO_simpgeol.pdf) and } \\
\text { explanation } \\
\text { (CO_geolexpl.pdf) }\end{array}$ & $\begin{array}{l}\text { H2O, Q_uncons, Q_basalt, T_uncons, T_sed, T_vclast, } \\
\text { T_volc, T_pluton, K_sed, KJ_sed, J_sed, JTr_sed, } \\
\text { Tr_sed,TrP_sed, Perm_sed,Tr_Penn_sed,P_Perm_sed, } \\
\text { Penn_sed, Mz_sed, MDOC_sed, Camb_sed, Camb_int, } \\
\text { Y_sed, YX_intr, YX_met, W_met }\end{array}$ \\
\hline \multirow[t]{4}{*}{6} & Claim Activity & CO_claim (thematic) \\
\hline & (CO_minclm.pdf) & CO_state \\
\hline & & CO_dists \\
\hline & & CO_cnty \\
\hline \multirow[t]{5}{*}{7} & Mineral Deposits & CO MRDS \\
\hline & (CO_allmin.pdf) & CO_MAS \\
\hline & & CO_dists \\
\hline & & CO_cnty \\
\hline & & CO_state \\
\hline \multirow[t]{5}{*}{8} & Placers & CO_MRDS \\
\hline & (CO_placer) & CO_MAS \\
\hline & & CO_dists \\
\hline & & CO_claim (thematic) \\
\hline & & Q_uncons \\
\hline
\end{tabular}




\section{FIGURES (.pdf)}

1. Index map of Colorado, showing location of mineralized areas, counties, major towns and highway. (CO_index.pdf)

2. Map showing mineralized areas in Colorado. (CO_mnarea.pdf)

3. Map showing distribution of selected metallic minerals in Colorado. MRDS shown as squares, MAS/MILS locations as circles. Any deposit containing, as the primary commodity, chromium, cobalt, or nickel shown in blue; tin or tungsten in lavender; molybdenum in pink; gold, silver, or platinum group elements in red; copper, lead, or zinc in green; and iron or titanium in brown. (CO_metdep.pdf).

4. Thematic map showing simplified land ownership in Colorado. (CO_lndown.pdf)

5. Simplified geologic map of Colorado (CO_geol.pdf) and explanation (CO_geolmap_expl.pdf).

6. Map showing intensity of claim activity in Colorado from 1976 to 1996. Intensity of open claim activity shown in shades of red superimposed on closed claims in shades of blue. (CO_minclm.pdf)

7. Map showing distribution of mineral deposits in Colorado (CO_allmin.pdf). CO_MRDS shown as squares, CO_MAS locations as circles, industrial materials may use different symbols (see map explanation for details, CO_allmin_expl.pdf).

8. Map showing location of placer claims and deposits in Colorado. (CO_placer.pdf) 